\title{
THOUGHTS ON THE NEW DADAIST TACTIC OF OUR ERA: 'SWEDED FILMS' AND MICHEL GONDRY'S BE KIND REWIND
}

\author{
Pelin AYTEMIZ \\ Başkent University, Turkey \\ paytemiz@baskent.edu.tr
}

\begin{abstract}
Be Kind Rewind (2008), comedy-drama film written and directed by Michel Gondry, can be considered as an alternative film as it has initiated a novel and subversive cultural practice called "sweding". Sweding, initially a term used by the characters of the film that describes their amateur way of remaking the famous cult films, started to be a marginal phenomena and adopted by crowds as a tactic of subverting dominant ideologies of mass culture. The meaning of sweding cut across its original meaning as a way of producing homemade films and started to be described as any kind of practice of re-creating something from scratch using commonly available, mundane everyday objects and skills. This idea of remaking has a critical and subversive potential. In this sense, this paper aims to engage in a critical analysis of Be Kind Rewind's ability to shift meanings of filmmaking using the criticism of Collin McCabe's "Classical Realist Text" and trace the subversive and alternative elements of this cultural phenomenon of sweding. It will be argued that the style and amateur film production associated with sweded films recall the techniques of the 20th-century art movement Dadaism that questions art and comments on daily life practices. Departing from this observation, the paper will open up the new "genre" of "Sweded Cinema" to further questioning and suggest that there is a potential in Sweded Cinema in challenging Classical Hollywood Cinema just like the way Dadaism countered high art and dominant ideologies of its time.
\end{abstract}

Keywords: visual culture, sweding, everyday life, Michel Gondry, dada, remake, genre.

\section{DÖNEMIN YENI DADAIST TAKTIĞİ: “SWEDED" FILMLER VE MICHEL GONDRY'NIN LÜTFEN BAŞA SARIN FÍLMI ÜZERİNE DÜŞÜNCELER}

Öz

Michel Gondry tarafinda yazılıp yönetilen komedi-drama türündeki Lütfen Başa Sarın (Be Kind Rewind, 2008) filmi, sweding adı verilen yeni ve eleştirel bir kültürel uygulama başlatması nedeni ile alternatif bir film olarak görülebilir. Filmde amatör olarak kült filmleri yeniden çeken karakterler tarafından kullanılan sweding kelimesi, sonraları marjinal bir fenomen haline gelerek, kitle kültürünün hakim ideolojilerine karşı gelen, eleştirel bir taktik olarak kişiler tarafından kullanılmaya başlandı. Sweding kelimesi orijinal anlamı olan amatör ev yapımı film üretimi anlamının ötesine geçerek, gündelik sıradan objeleri ve yetenekleri kullanarak sıfırdan üretim yapmanın tüm çeşitleri olarak tanımlanmaya başladı. Bu yazı bu tip bir yeniden üretimin eleştirel ve karşı çıkıcı bir potansiyeli olduğunu düşünmektedir. Bu bağlamda bu makale Colin McCabe'in "Klasik Realist Metin" üzerine olan eleştirisini kullanarak Lütfen Başa Sarın'ın film üretimini sorgulayan yapısına ve kültürel bir fenomen olarak sweding eyleminin alternatif yöntemlerine odaklanarak filmin eleştirel bir okumasını yapar. Bu yazı sweded filmler ile ilişkilendirilen stil ve amatör film üretiminin, sanatı sorgulayan ve gündelik hayatı yeniden yorumlayan 20.yy sanat akımı Dadaizm'in tekniklerini hatırlattığını öne sürer. Bu gözlemden yola çıkan yazı, "Sweded Sinema" adı altında anılan bu "türü" tartışmaya açar ve tıpkı zamanında Dadaizmin klasik sanat ve hakim ideolojilere meydan okuduğu gibi, bu yeni türün de Klasik Hollywood Sinemasını eleştirme potansiyeli olabileceğini tartışır.

Anahtar Kelimeler: görsel kültür, sweding, gündelik hayat, Michel Gondry, dada, yeniden üretim, tür 


\section{INTRODUCTION}

The new artist will create an art 'without any argument,' that is no longer a symbolic and illusionist reproduction of external objects, but will work directly in stone, wood, iron, tin-rocks and moving organism susceptible of being turned this way and that by limpid wind of momentary sensation.

Manifesto Dada $1918^{1}$

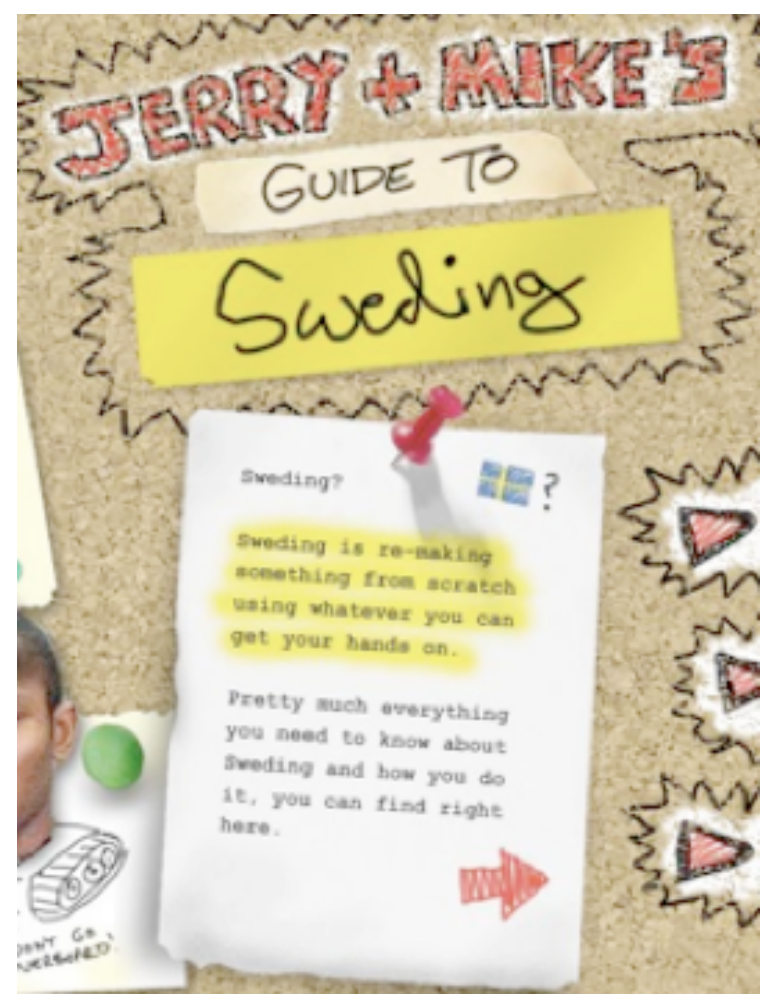

Image 1. Jerry and Mike's guide to Sweding. ${ }^{2}$

Be Kind Rewind (2008), comedy-drama film written and directed by Michel Gondry, can be considered as an alternative film both because of the director's unique experimental style that relies on videography - analog camera tricks and the film's ability to initiate a novel and subversive cultural practice. The film introduces a concept called "sweding" that is a made up word proposed by the characters of the film. Although it is an invented term belonging to the fictional world of the film, it has started to be a part of the popular culture and adapted in language by crowds as an extra-diegetic element. It is possible to encounter with the definition of this artificial term in many online dictionaries. Moreover, one can find several examples of sweded films and products, particularly on the Internet. ${ }^{3}$ The word "sweding" finds a place in the language and is practiced by alternative groups. Referring to the narrative of the film, sweding is described by the characters in the film (see image 1) and online in these words:

Sweding is the practice of re-creating something from scratch using commonly available, everyday materials and technology. Items that are "Sweded" look distinctively homemade,

\footnotetext{
${ }^{1}$ Tzara; as cited in Erickson, Jhon. 1996: 16

${ }^{2}$ Retrieved from http://tcritic.com/ (11.08.2015)

${ }^{3}$ One can find sweded film compilations in the following links: http://swededcinema.com/, http://swedefest.com/, https://www.youtube.com/results?search_query=sweded+films, http://nofilmschool.com/2014/04/video-swedes-70-iconic-films-whats-sweded-cinema-again
} 
often bearing only the slightest resemblance to the original. While naïvely rendered, "Sweded" items are usually charming and highly amusing. ${ }^{4}$

Lately sweded films and sweded videos go beyond the realm of the virtual culture and also welcomed by film festivals. There are several film festivals solely devoted to sweded cinema which regards them as a unique genre on its own (See image 2 and image 3 )

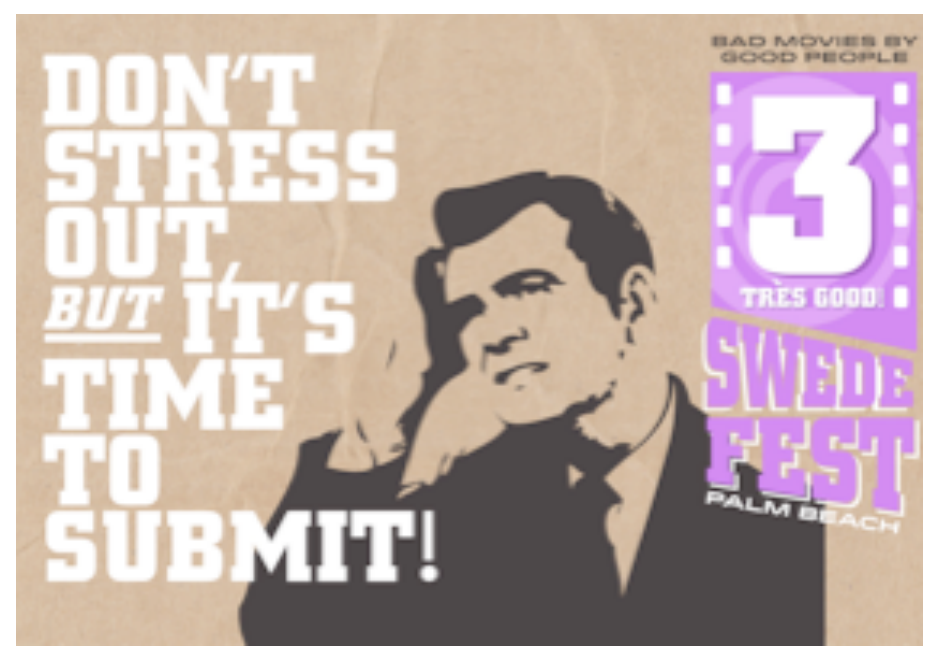

Image 2. The advertisement of Sweded Film Festival of Palm Beach that is realized on August 2, 2014 , in which 45 sweeded films have been submitted for evaluation. ${ }^{5}$

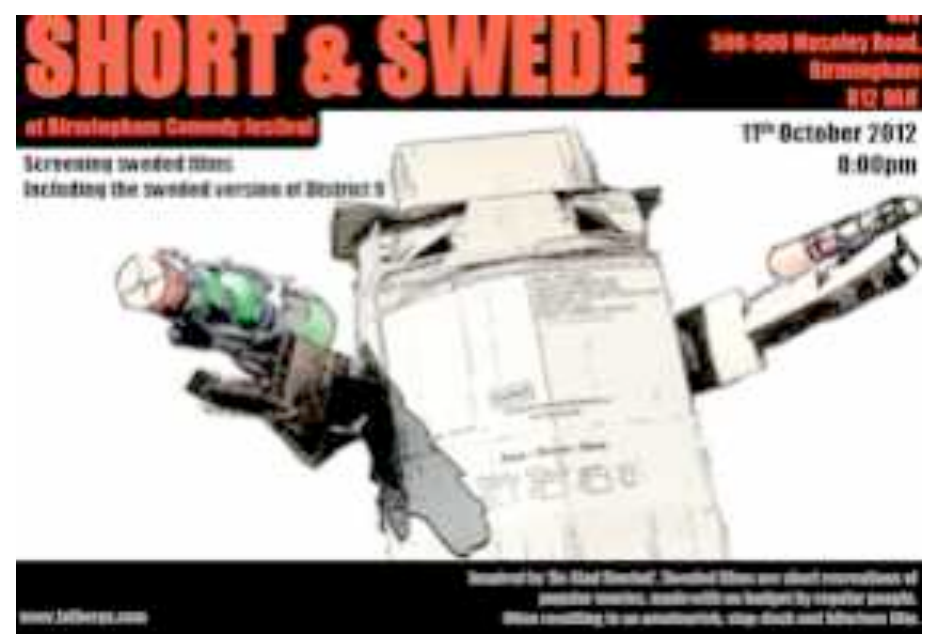

Image 3. The flyer of the film event 'Short and Swede' in London. ${ }^{6}$

Be Kind Rewind has an absurd story that is about Mike (Mos Def) and his crazy friend Jerry (Jack Black) who has to look after a VHS rental store owned by Mr. Fletcher (Danny Glover) as Mr. Fletcher goes away to spy on "successful" DVD rental stores in order to make money to amend his business. Unfortunately, one day Jerry becomes magnetized in an attempt to sabotage an electric station. When he gets in the VHS rental store in his magnetized state, all the VHS tapes are accidently erased. Mike and Jerry discover the disaster and to hide the problem from Mr. Fletcher. They decide to recreate and reshoot the classical movies with an amateur spirit. They naively attempt to pass their parodied versions as the original films. They act and use cheap special effects and costumes to remake famous cult movies like 2001 Space Odyssey (1968, Stanley Kubrick), Ghost Busters (1984, Ivan

\footnotetext{
${ }^{4}$ Retrieved from https://solsticedigital.wordpress.com/2008/01/18/bharvey/ (03.03.2016)

${ }^{5}$ Retrieved from http://swedefestpalmbeach.com/ (11.08.2015)

${ }^{6}$ Retrieved from http://fatbergs.com/tag/swedes-2/ (11.08.2015)
} 
Reitman), Back To The Future (1985, Robert Zemeckis), Robo Cop (1987, Paul Verhoeven), Driving Miss Daisy (1989, Bruce Beresford), Lion King (1994, Roger Allers; Rob Minkoff), Rush Hour (1998, Brett Ratner) and so on. They call their version of the homemade movies as "sweded". Later, sweded versions of the films become very popular, and they turn into marginal celebrities and by this way, they are able to save the VHS Store.
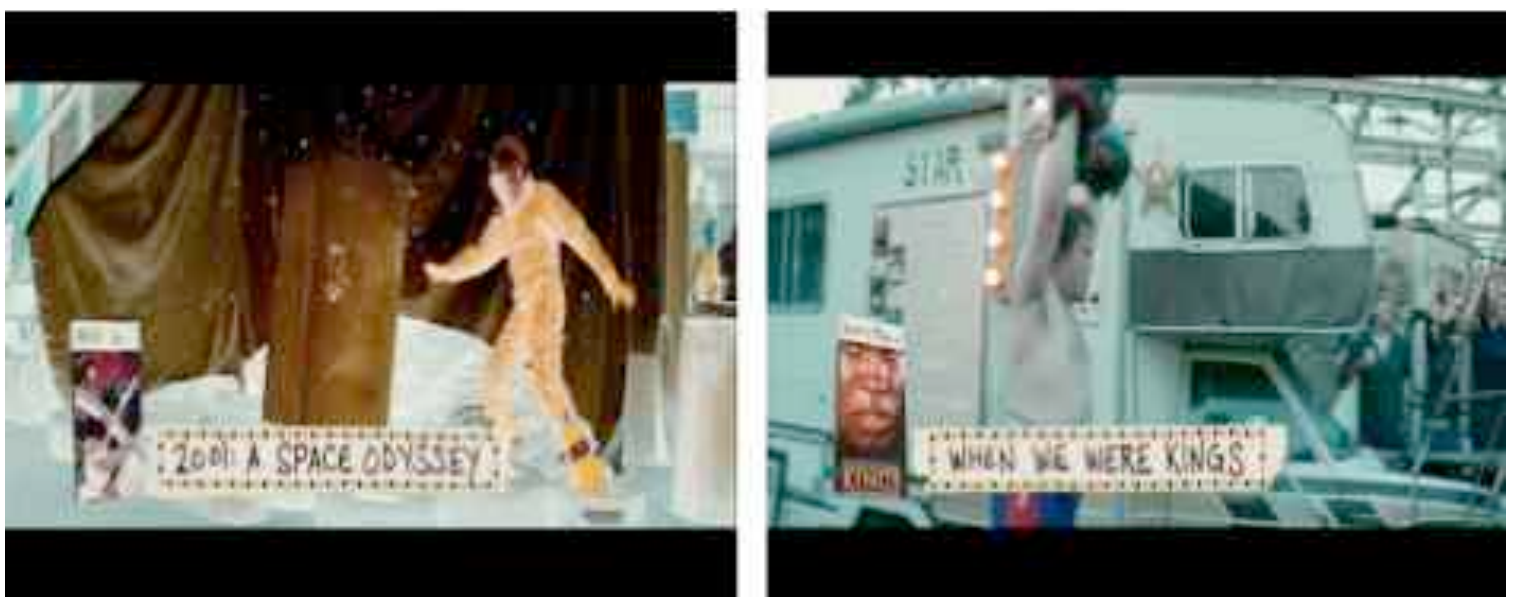

Image 4 Screen Shot from Be Kind Rewind Image 5 Screen Shot from Be Kind Rewind

The idea of remaking films at home using everyday materials in an amateur way may have a critical and subversive potential. In this sense, this article concentrates on Be Kind Rewind's and its directors ${ }^{7}$ ability to shift meanings of filmmaking and trace the subversive and alternative elements of this cultural phenomenon of sweding driven from the techniques of the 20th-century art movement Dadaism. The research uses Collin McCabe's understanding of "Classical Realist Text", and drives a discussion of realist and post-realist texts and the way "Sweded Cinema" has subverted Classical Hollywood Cinema just like the way Dadaism has countered high art and dominant ideologies.

\section{A DADAIST WAY OF FILMMAKING: SWEDED CINEMA}

Walter Benjamin in his famous article "The Work of Art in the Age of Mechanical Reproduction", discusses new forms of producing art and its consequences for the capitalist industry of the early 20th century. For Benjamin, the authority, that is to say; the cult value of the artwork is lost when it is mechanically reproduced. What Dada is attacking is precisely the same cult value of artworks, which is assigned to a privileged class. Erickson writes that "far from introducing a cult of the object - the object as a fetish- the Dada has brought about a liberation from the ritual and cultural conditioning that inhabits and predetermines the response of the reader-beholder"' (Erickson, John. 1996: 10). By deaestheticization of cultural artworks ${ }^{8}$ Dada attacks the uniqueness, in brief, the aura of artworks. In this context, how can we make sense of Michel Gondry's effort of making use of cult films of our era? In this sense, the naïve narrative of the film, which can also be regarded as an ode of Gondry to analogue technologies, can also be read as a comment on the contemporary battle among analogue vs. digital technologies and the never-ending theoretical discussion of the "aura" of the original work of art, both in the age of mechanical (Benjamin, 1970) and digital reproduction. In the light of recent developments in digital recording technology, Benjamin's essay and his concept aura is being reassessed by scholars (Lister, Martin 1997; Robins, Kevin 2001; Link-Heer, Ulla 2003; Shiff, Richard 2003; Nichols, Stephen 2003; Sasoon, Joanna 2004) of cultural theory. Predictions made by Benjamin in the 1930s are re-evaluated and re-read. The main question in these debates is whether a second revolution is happening in visual culture with the transition to digital. When a reassessment of Benjamin's argument in the context of the recent technological and social developments is made, several scholars have argued that mechanical photography begins to regain an auratic value in contrast

\footnotetext{
${ }^{7}$ This style of sweded films aldo recalls the creative techniques the director also uses in his cinematographing choices and way of his unique film producing style that is full of artwork and ametaur spirit.

${ }^{8}$ For example the famous 1919 work entitled L.H.O.O.Q by Marcel Duchamp in which he uses a postcard reproduction of Leonardo da Vinci's Mona Lisa and drew a mustache and beard and gave a title.
} 
to Benjamin's view. For example, Dirk Baecker (2003:9) suggests that aura is not disappearing like the way Benjamin suggested. In contrast, there is almost an inevitable reappearance of aura as a result of technological developments. In this conceptualization of aura in the age of digital reproduction, I wonder if one can consider the classical cult movies as having a kind of aura although it is an example of a mechanical reproduction. In this sense, one can regard them as entailing a kind of uniqueness and singularity. Thus, if they gain a kind of a cult value, then one can talk about a striking similarity between remaking such cult films via sweding and drawing a mustache to Mona Lisa like the famous Dadaist work of art, as they both attack their authority, aura and cult value. Driving from this theoretical background, in the following part of the article, I would like to trace the Dadaist nuances in Gondry's avant-garde film Be Kind Rewind.

Altgough the film Be Kind Rewind seems to be a product of postmodern age, it can be regarded as borrowing the techniques of the modernist art movement of Dadaism. Dada emerged in 1916 as a response to the violence and trauma of World War I and the shock of Modernity. They developed scandalous tactics of their own through using explosive language and shocking visions. They critiqued traditional understanding of the artist as the master of his work of art. They used prefabricated materials, included stuff of modern life (such as; newspapers, magazines, tickets, pipes, advertisements, light bulbs and so on) and made aesthetic decisions depending on chance. They asked, "what a work of art" is and mainly questioned the boundaries between art and life. Be Kind Rewind can also be regarded as having a similar progressive attitude especially towards the art of filmmaking as it asks the crucial question of "what is filmmaking?" Moreover, the film introduces an alternative way of filmmaking: sweding and constructs new conventions and codes that seem to be borrowed from the Dadaist movement. Be Kind Rewind makes filmmaking and the rules of film industry visible, and thus can be regarded as having a critical standpoint.

According to many critical film theoreticians (McCabe, 1974; Baudry, 1970; Bazin, 1967), Classic Hollywood Cinema has its rules, norms and conventions to create an "impression of reality", which has certain ideological implications. McCabe's (1974) analysis provides an account of the "invisible" operations of the camera and results in a "dominant specularity" that is created via a number of techniques like having codes for continuity editing, (180 degree rule, shot-reverse shot pattern, eyeline match, cutting within 180/30 degree rule, match on action cuts and so on) having a structure of "equilibrium - disequilibrium- new equilibrium", having a temporal plot order, closure etc. Collin McCabe (1974) regards the process of watching, what he calls the "Classic Realist Text", as creating an illusion that the spectator sees himself/herself as the independent, autonomous individual. McCabe borrows Louis Althusser's concept of "interpellation" and regards such films as interpellating the spectator and positions the subject in ideology. Such a structure prevents the spectator from questioning what they are watching and cannot escape the dominant specularity created. In this sense, McCabe elaborates ways to break this "illusion of reality". He proposes Brechtian techniques for an understanding of counter-cinema such as alienation, defamiliarization effect, interrupting the action, actors playing multiple roles, actors addressing the audience directly etc. Bertold Brecht, who was also inspired by the techniques of the Dada's, explains the purpose of the alienation effect as "to alienate the social behavior that underlines all events. I mean by social behavior the mimic and gestural expression of social relationships, which people of a given epoch share with one another" (qtd. in Bergius, Hanne 1996:117). Although Be Kind Rewind borrows some conventional storytelling structures of Classical Hollywood Cinema (it still has a linear plot perfect for the mainstream audience. It even includes a love story and a happy ending), it can be regarded as including Dadaist Brechtian structures that can be regarded as working to shatter the illusion of reality many film theoreticians are critical of. In Be Kind Rewind, there is a high motivation of the characters (to save the future of the VHS Store) to remake the famous examples of Classical Hollywood Films. This reason lets the narration move forward similar to the structure of Classic Realist Text, throughout the film. But, what is interesting is the potential critic aspect of this motivation of the characters. Film- withinfilm structure makes the rules of the conventional cinema visible of the spectator. The film-within-film idea certainly isn't new, but Be Kind Rewind elaborates this familiar idea by layering it not just one additional movie, but also an excessive number of 18 films. In this sense, the film has a kind of Brechtian self-reflexive attitude that problematizes the art of filmmaking itself and breaks the illusion 
of reality of the text again and again several times. This can be regarded as a Dadaist attitude as Dada "in general of the late nineteenth and early twentieth centuries developed, through irony, counterdiscourses that attacked the master narratives of progress and perfection" (Erickson, Jhon. 1996: 10). Here, Classic Hollywood Cinema is the master narrative, which Michel Gondry seems to attack.

Dada, as a counter art movement, is not just a search for new aesthetics but also a search for reorienting a new relationship to the world in general. It not only wanted to change the art, but also life itself. It aimed to regenerate life, using art. Similarly, Be Kind Rewind is not only a film but by starting the phenomena of sweding leaks through the culture and begins to exist in it. Every time it is practiced, it comments on the nature of the cinema and the way the film industry works. It introduces a Dadaist way to attack the general narratives, which its followers can practice in an amateur way in their daily life. That is why, this practice can be considered as an example of Michel de Certeau's tactics, which are discussed in the conclusion part of this essay. As Allen Roy says; Dada "aimed at the liberation of the individual from dogmas, formulas and laws, at the affirmation of individual on the plane of spiritual; it may even be said that the movement liberated the individual from the mind itself, placing the genius in the same rank as the idiot" (1996: 68). Sweding also doesn't seem to follow the formulas of classical filmmaking industry, but instead, the stress is given to its homemade quality and absurdity. The main actor of the film Jack Black explains the word sweding and its rules as follows:

Hey! How is it going I am Jack Black, I am here to encourage you to swede your own movies. Sweding is a process, new phenomena, making ripples throughout the entertainment industry, what you do is you videotape your own version of your own favourite movies and put yourself in there, and you make it short and kind of puff crappy, but still magical because you are in it and because it is your home made version. And you know what you can upload it to this site, www.bekindrewindyourmovie.com.

Gondry and Black invite their fans to make their version of the films they like. Even they start a competition of sweded films that people are encouraged to upload their amateur videos to the web page via Youtube. The director Gondry also sweded a version of the trailer for his film that stars himself. The motto of sweding is that anyone can do it. No large budget is needed; no 3D special effects are wanted. Improvisation and ingenuity are encouraged. Everybody can Swede like "Everybody can Dada" (Dada-Fair, Berlin, poster, 1919).
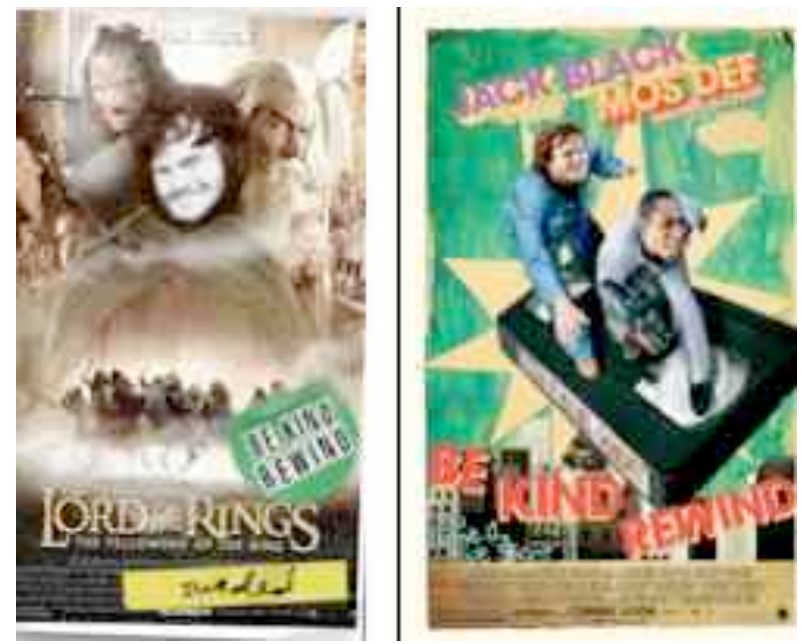

Image 6 Official poster design of Be Kind Rewind. ${ }^{9}$

Image 7 The VHS Cover of Sweded Lord of the Rings

The early stages of Dada as an informal international art movement of the European avant-garde is parallel to the outbreak of World War I. The movement started as a protest to the nationalist,

\footnotetext{
${ }^{9}$ Retrieved from http://www.imdb.com/title/tt0799934/ (12.08.2015)
} 
colonialist and bourgeoisie capitalist society, which Dadais believed that their 'reason' and 'logic' is what led the society into war. Thus, Dadaist perspective embraced and prized 'chaos', 'randomness', 'irrationality' and 'intuition' in their artistic works as an expression of rejection of that ideology that claims to be reasonable and logical (Budd, 2005). The art techniques developed in Dadaism are collage, photomontage, assemblage, ready-mades, abstraction typography, sound poem, chance, over painting, and photography (Motherwell, 1989) in order to challenge high art and anything related to traditional psyche and traditional aesthetics. For the avant-gardist Hans Richter (1965) Dada was not art at all, it was "anti-art" and was a form of expression that positioned itself as an opposite of all what traditional art stood for. If we consider the techniques of Dada, one can say that it has a tendency to reject artificial or mass-produced materials. It favors the preindustrial aestheticism, which can also be seen in the structure of Be Kind Rewind.

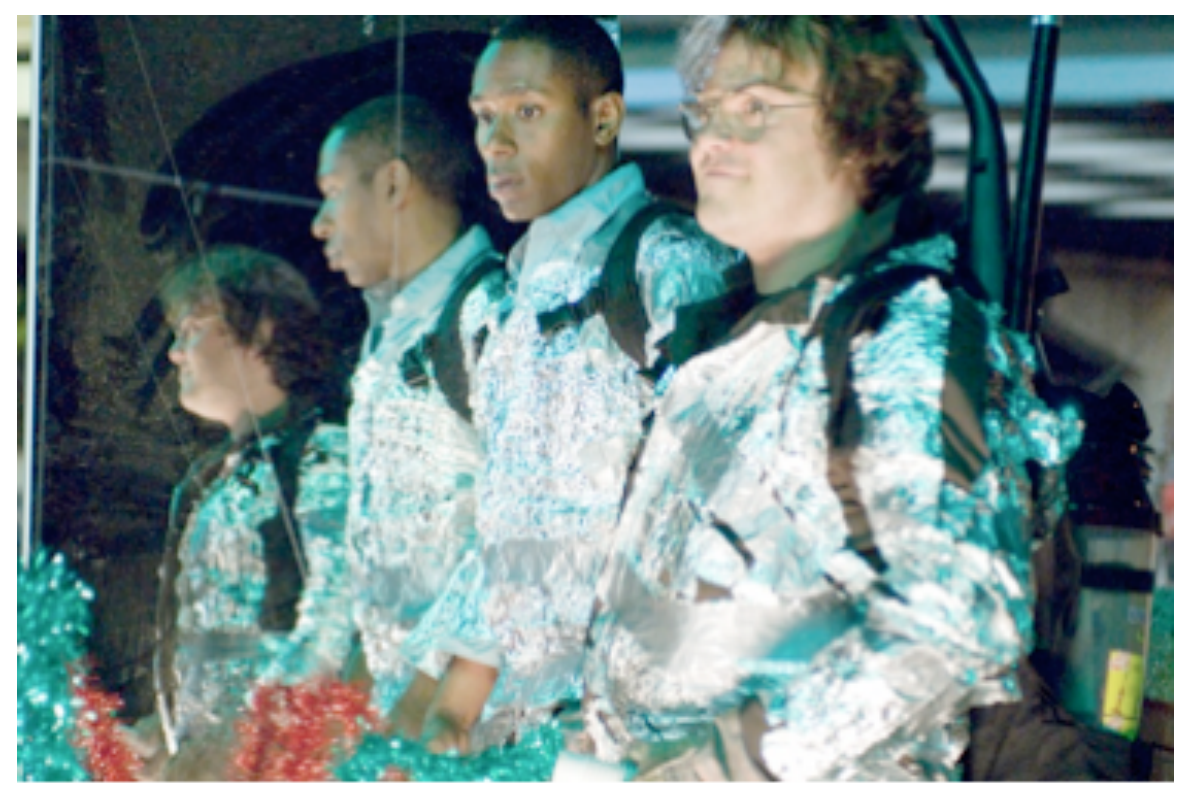

Image 8 Characters are sweding Ghost Busters in Be Kind Rewind. ${ }^{10}$

The famous Dadaist artist Marcel Duchamp began to use found objects and view the manufactured objects as art, which he called "ready-mades". He would add signatures and titles to some and declare them a form of art. The famous example of Duchamp's readymade work is the urinal, titled "Fountain". One can say that in Be Kind Rewind the Classical Hollywood Films acts like found footages as artifacts of everyday life and popular culture, just like the ordinary found objects used in Dadaist movement. The ready-made project of Marcel Duchamp's "fountain" recalls the re-made sweded films of Jerry and Mike in which one opposes the traditional art; the other challenges the Classic Realist Text of the Hollywood. In this sense, one can trace a similar Dadaist spirit and technique in Gondry's film. Throughout Be Kind Rewind, the challenge is to change the quality of available everyday materials to a prop, a part of a costume or using them for creating a special effect or sound effect for their sweded versions (See image 4 in which a refrigerator is used in the décor of the sweded Space Odyssey.) Fans of the film are encouraged to use what they find around, just like the found objects of Duchamp's ready-mades, and improvise their way of filmmaking with the mundane materials available around them. Such a re-contextualization of everyday objects are seen in Dadaist movement as John Erickson writes when describing the action; "artistic sensibility, chance in transforming the object by destroying and radically reconfiguring its context, underscores the creativedestructive nature of the Dada artistic-poetic-cultural act" (1996: 17). One can see many examples in the film where Mike and Jerry use everyday objects such as aluminum folio, fishing equipment, New Year decorations, cardboards (see the screen shot in image 8 where they are sweding Ghost Busters) in order to create a sweded scene. These examples have a similar attitude to Dada as they "sought the metamorphosis of objects into signs" (Erickson, Jhon. 1996: 17). On the other hand, the assemblage -

\footnotetext{
${ }^{10}$ Retrieved from http://videocitylondon.com/2013/05/06/michel-gondrys-sweded-taxi-driver/ (11.08.2015)
} 
the three-dimensional variations of the collage technique - can be seen in the mise-en-scene (the costume, setting, lighting, props) creations of the sweded films of Mike and Jerry. Not only everyday life objects but also words from the ordinary world are used in an arbitrary way as a technique in Dadaist poetry. Making up words, and selecting words in a random way to write a poem is a typical characteristic of the art movement Dadaism. Even the name of the movement "dada" reflects the same principle and comes from a nonsensical phonetic word (Budd, 2005). "Sweding" as a made up word, entails this technique in itself, which can also be regarded as reflecting the film's avant-garde spirit. Moreover, the official poster of the movie and the VHS covers of sweded films used in Be Kind Rewind seem to be parallel to the anti-aesthetics of Dada (see image 6 and image 7). It is typical for a Dadaist to use scissors and glue as in the Dadaist collage and photomontage the pasting of cut pieces of paper items are very much welcomed, just like the hand-crafted parts of the mise-en-scene of $B e$ Kind Rewind

Dadaist movement also uses parody as a tool to counter the prevailing standards in art and reflect its politics of producing anti-art cultural works. "The Dada's developed a counter propaganda through parodical imitation of deceptive appearances" (Bergius, Hanne 1996: 117). Correspondingly the very nature of sweded films includes a nuance of parody, as they are the imitations of an already existing classic cult movie. Parodies trigger an element of laughter, which can be subversive. According to Linda Hutcheon "parody signals how present representations come from past ones and what ideological consequences derive from both continuity and difference" (1989: 93). Depending on her definition, one can say that Be Kind Rewind is an attempt to reread the past examples of cult movies and questions some conventions and codes of classical narratives. Sweding films has the potential of subverting the powers of traditional cultural representations. According to Hutchen, when there is a reproduction or a parody there is always an element of excess. Parodic style operates at two different levels first is the recognition of similarity or sameness, and then comes the recognition of difference. The element of excess creates an element of satire. The satiric impulse created, evokes a laughter that includes a critical comment. In this sense, parody has a critical potential. The audience recognizes what is being performed and laughs at the exaggerated performance. This excessive element makes one think about the element that is being performed critically. The excessive side of the sweded films that are shoot by crowds and uploaded to Youtube may present many subversive issues about gender, identity, patriarchy, family unit and so on as they mostly use stereotypical characters. The awareness of genre conventions becomes a parody, which ends with a source of humor and presents a potentially critical arena.

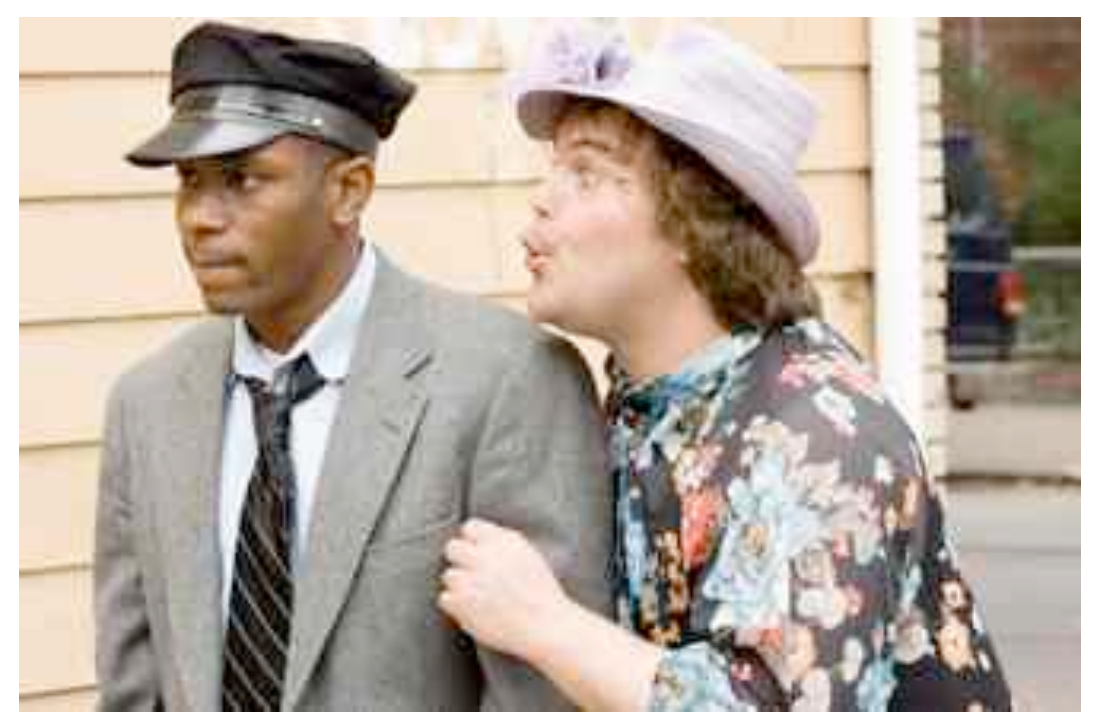

Image 9 Mike and Jeff Sweding Driving Ms. Daisy

\section{EVERYBODY CAN DADA - EVERYBODY CAN SWEDE}



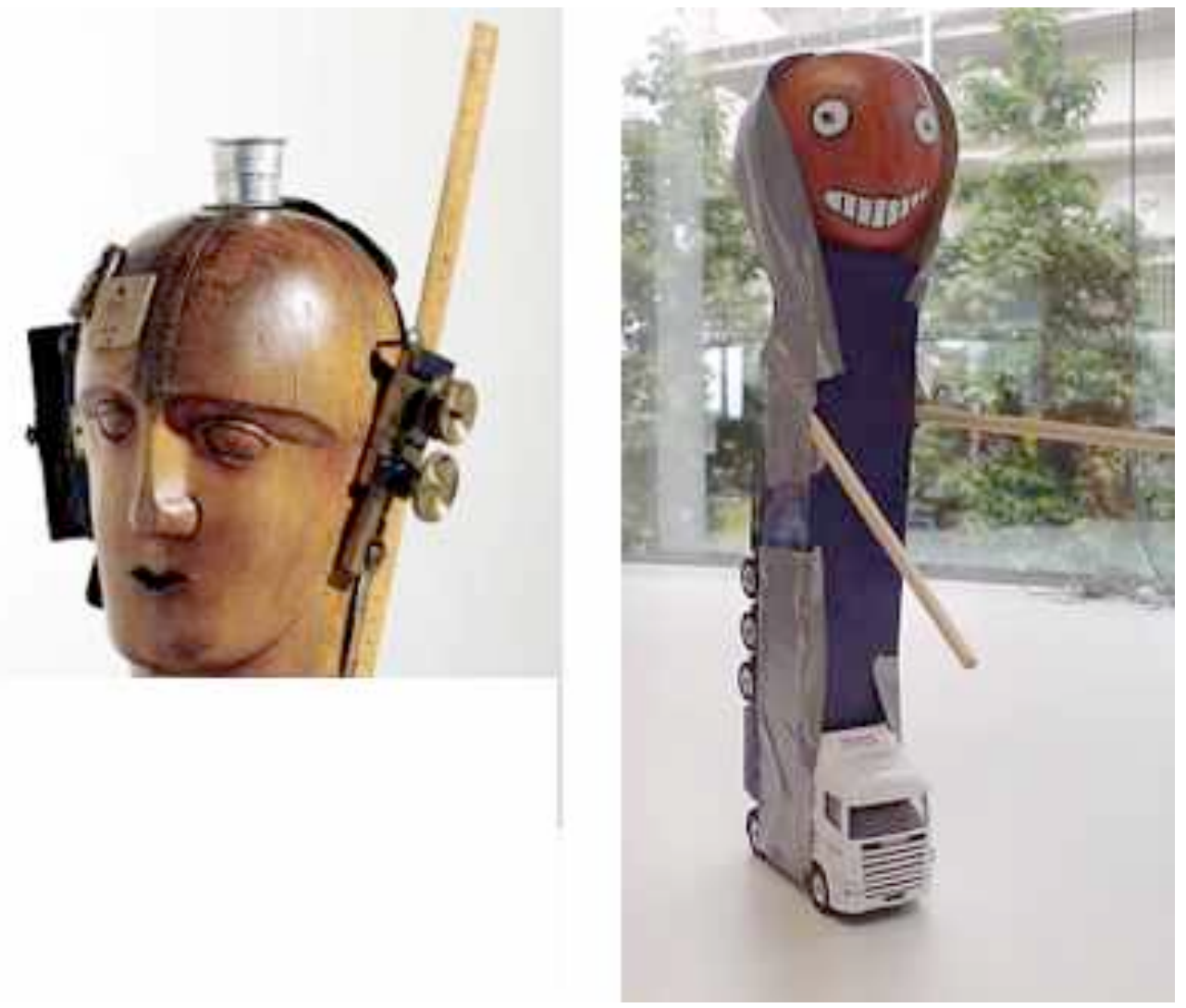

Image 10. Dadaist Raoul Hausmann’s Mechanical Head 1919 Image 11. Transformers by Ben Harris

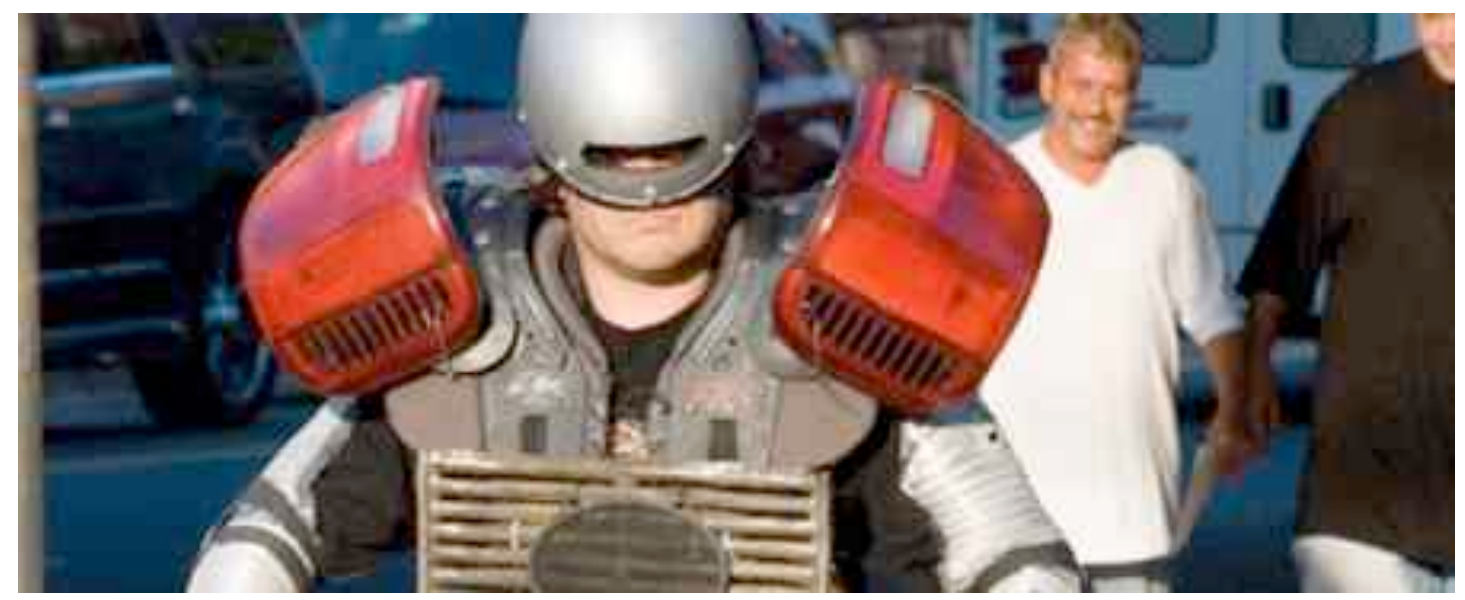

Image 12 Robocop By Michel Gondry in Be Kind Rewind

Roland Barthes famous book Mythologies published in 1957 is a collection of essays examining social values and beliefs, certain rules and conventions that create what he calls "Myth". The myth is "a type of speech" (Barthes, 1957) that is formed to perpetuate the society that holds on the dominant ideologies of the ruling class. The socially constructed notions, codes, narratives become naturalized and taken for granted in the functioning of myths. Myths which are peculiar meanings which are specific to certain groups, are made to seem universal. For sure, cult examples of Classical Hollywood Films work in perpetuating existing myths of our society. I have discussed the ways Be Kind Rewind (via the creative practice of sweding) attacks such socially constructed notions, narratives; via using Brechtian method of self-reflexivity, using techniques of Dadaism, entailing subversive side of parody in itself. In relation to Barthes concept myth, one can say that the practice of sweding can also be regarded as attacking the myth of Classic Hollywood Cinema. How can one undo such a grand myth of Hollywood? For Barthes (1957), it is difficult, as a myth does not hide anything, it distorts and 
"transforms history into natüre". It proposes as if the subject matter is eternal, not to be questioned. It naturalizes the myth. So for him, the best weapon to counter a myth is to mythicize it in its turn. That means to create an artificial myth. In this sense, I ask; can we say that by creating the phenomena sweding Gondry elaborated an artificial myth, which presents a way of mythicizing the myth of Classical Hollywood Films. Myths are historical and can only emerge from a historical foundation. So, one should consider sweded films in its historical context. Also, one should also acknowledge the fact that popular culture and advertising culture have strong strategies that know how to use and assimilate such alternative practices. Sweding, now a counter practice can also turn out to entail an authority and become a myth one day. In this sense, I think it can be a way to subvert the cultural hierarchies of the existing film industry and filmmaking practice.

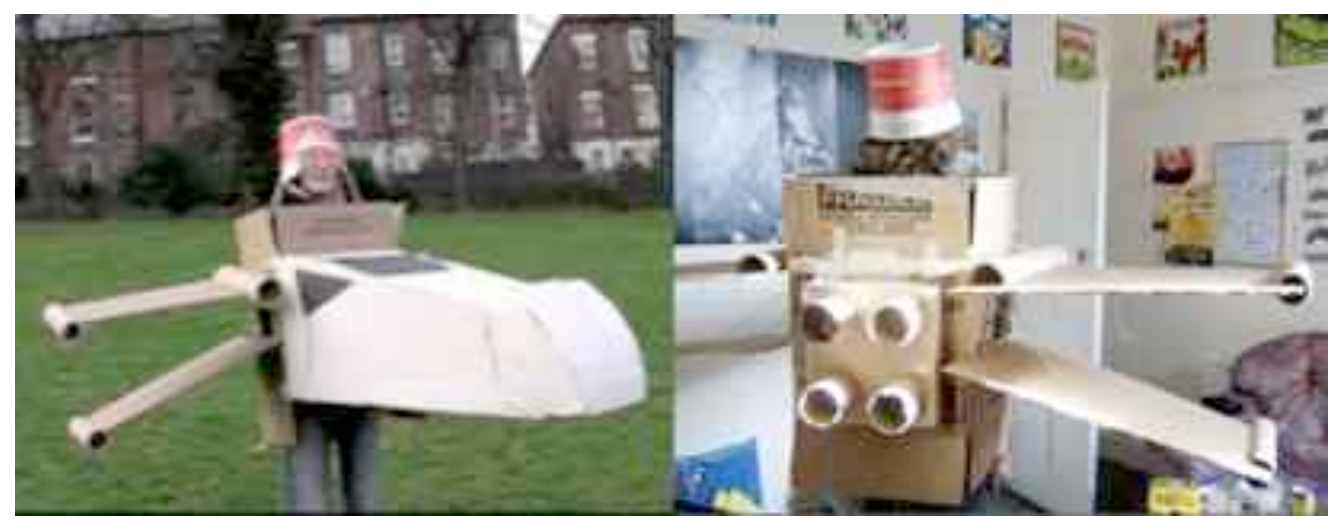

Image 13 A sweded version of Star Wars from a Sweder's video.

Along with the examples of sweded films that can be found on the web, there are other projects sweding is being adapted by the crowds and practiced eagerly. In the production notes of Be Kind Rewind, there are many examples of other sweding practices and products, different than sweded films. ${ }^{11}$ Sweders include actor, dancer and choreographer Michael Patrick Breen; Lego artist Sean Kenney; blogger Ben Harris and multimedia artist James R Ford. For example Michael Patrick Breen swedes popular TV serials such as Grey's Anatomy (2005, Shonda Rhimes), E.R (1994, Michael Crichton) and Criminal Minds (2005, Jeff Davis) as a kind of sweding practice. Lego artist Sean Kenney's sweded version of Google and Google made up via Lego parts entails a practice of reappropriating issues of 'art' in everyday life situations, which can be discussed in relation to the famous work of Michel De Certeau's (1994) The Practice of Everyday Life. It is an analysis of how one individualizes mass culture and alters ordinary things in order to make them their own in a subversive way. He argues that ordinary people have the power to subvert the rituals that institutions seek to impose upon them. Everyday life is a side of struggle against the grand institutes of dominant order and its products (such as law, language, literature, art) that uses strategies to perpetuate itself. The ordinary ones attack these strategies unconsciously by what Certeau calls tactical activities. The "tactics", unlike the "strategies" that entail an authority, lacks centralized structure. It manifests itself in methodology and is performed by individuals. The tactics do not aim to win or overtake like the strategies do. It is a way of subverting powers that define everyday mundane situations. In this sense, all examples of sweding can be regarded as an example of Certeau's tactical activity, which has a potential of countering grand narratives of the dominant ideologies. In the practice of sweding with films, cardboard, acting, etc. one can track a counter discourse for mass culture, capitalist film industry. By the practice's Dadaist nuance and tactics of the ordinary, the so-called passive, noncreator consumer of popular culture, which is, subject to receive the culture; seems to counter and change.

\footnotetext{
${ }^{11}$ Published from the official web page http://www.newline.com/properties/bekindrewind.html.
} 


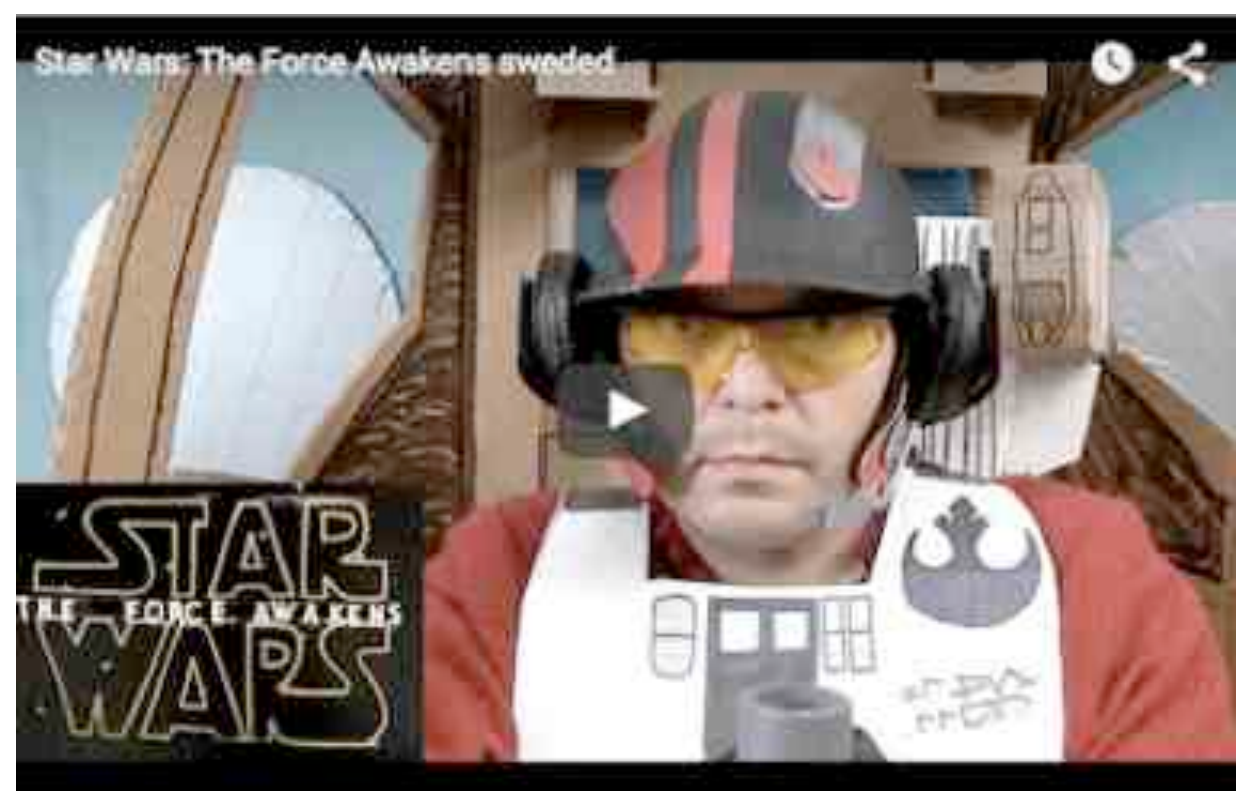

Image 14. Star Wars: The Force Awakens trailer sweded by a fan. ${ }^{12}$

In order to conclude the issues raised in this analysis of Be Kind Rewind and sweded film, I would like to ask weather this seemingly Dadaist way of filmmaking might be a peculiar kind and a genre in film theory. The website http://swededcinema.com which archives the best-sweded films on the web regards sweded films as a separate genre introduced to film culture on 2008 and describes it as a film movement. Sweded film is really a genre? Or is it simply containing the same difficulties of drawing the boundaries of any genre? For the website the sweded video requirements are as follows:

(1) Must be based on an already produced film; (2) Range 2-8 minutes in length; (3) Must not contain computer-generated graphics; (4) Based on films less than 35 years old; (5) Special effects must be limited to camera tricks and arts 'n crafts; (6) Sound effects created by human means; (7) Hilarious.

There are two constituents that determine the genre of a film which are the narrative-plot and the iconography (costume, decor, light-colour, acting, choice of space). Yet, the sweded films come from any genre and have various iconographies and narrative, as they are parodies of already made films. But the mode of production and their amateur spirit are what makes them unique and define a common ground. The required qualifications of the sweded films listed on the website are like the tactics of de Certeau's that an ordinary one can follow and deconstruct the myth of Classical Realist Text. In this sense, sweded cinema is a peculiar way of expression that has a potential of criticizing its own period and its own society by sweding films.

This essay set out to examine a new kind of underground and ameteaur way of film-making that defines an alternative langauge which, as an extention of an everyday practice, naively decontructs Classical Narrative Texts. This decontruction comes from not only the power of parodying the mytical famous cult films that mark film history but also by the way these self-reflected sweded films calls ones attention to the production line of filmmaking. This article overall attempted to further the debate around critics on Classical Narrative Films by introducing an overlooked web-based film making practice; Sweded Cinema and discussed whether it is having a subversive potential depending on Dadaist tecniques which have proven to be an alternative art movement. What may need to be considered but is beyond the scope of this paper, is the perception of sweded films by sweded film makers and the reception of these amateur productions.

\footnotetext{
${ }^{12}$ Retrieved from http://blogs.indiewire.com/theplaylist/ (10.08.2015).
} 


\section{REFERENCES}

Baecker, D. (2003) 'The Unique Appearance of Distance' in Hans U. Gumbrecht and Michael Marrinan (eds) Mapping Benjamin: The Work of Art in Digital Age. Stanford: Stanford University Press: 9-24.

Barthes, R. (1957) Mythologies (trans). Annette Lavers. The Noonday Press. New York. Baudry, J. (1970) 'Ideological Effects of the Cinematographic Apparatus' in Leo Braudy and Marshall Cohen (eds) Film Theory and Criticism, Oxford: Oxford University Press: 345-355.

Bazin, A. (1967) What is Cinema (trans.) Hugh Gray University of California Press.

Bergius, H. (1996) 'Dada, the Montage and the Press Catchphrase and Cliché as Basic TwentiethCentury Principles' in Stephen Foster (eds) Crisis and the Arts the History of Dada NewYork: Simon \& Schuster Macmillan: 107-133.

Benjamin, W. (1970) 'The Work of Art in the Age of Mechanical Reproduction' In Hannah Arendt (eds) Illuminations (trans.) Harry Zorn. London Pimlico: 211-244.

Budd, D. (2005) The Language of Art Knowledge Cards, Pomegranate Communications, Menlo Park CA.

Certeau, M. (1994) The Practice of Everyday Life (trans.) Steven Rendall, Berkeley: University of California Press.Erickson, J. (1996) 'The Cultural Politics of Dada' In Stephen Foster (eds) Crisis and the Arts the History of Dada, New York: Simon Schuster Macmillan: 7-28.

Hutchen, L. (1989) The Politics of Parody' In The Politics of Postmodernism, New York: Routledge: 92-117.

Lister, M. (1997) 'Photography in the Age of Electronic Imaging' in Martin Lister (eds) Photography: A Critical Introduction. London: Routledge: 249-292.

Link-Heer, U. (2003) 'Aura Hysteria or the Lifted Gaze of the Object' In Hans U. Gumbrecht and Michael Marrinan (eds) Mapping Benjamin: The Work of Art in Digital Age. Stanford: Stanford University Press: 114-123.

McCabe, C. (1974) 'From Realism and the Cinema: Notes on Some Brechtian Theses' Anthony Easthope (eds) in Contemporary Film Theory, New York: Longman: 53-67.

Motherwell, R. (eds). (1989). Dada: Painters and Poets: An Anthology. Cambridge: Belknap Press. Nichols, S. (2003) 'The End of Aura' in Hans U. Gumbrecht and Michael Marrinan (eds) Mapping Benjamin: The Work of Art in Digital Age. Stanford: Stanford University Press: 256-268. Richter, H. (1965). Dada: Art and Anti-art, New York, and Toronto: Oxford University Press.

Robins, K. (1995). 'Will Image Move Us Still' in Martin Lister (eds) The Photographic Image in Digital Culture. London: Routledge: 29-51.

Roy, A (1996). 'Aesthetic Transformations: The Origins of Dada' in Stephen Foster (eds) Crisis and the Arts the History of Dada. New York: Simon Schuster Macmillan: 59-82.

Sasoon, J. (2004). 'Photographic Materiality in the Age of Digital Reproduction' in Elizabeth Edwards and Janice Hart (eds) Photographs Objects Histories: On Materiality of Images. London: Routledge: 186-203.

Shiff, R. (2003) 'Digitized Analogies'. In Hans U. Gumbrecht and Michael Marrinan (eds) Mapping Benjamin: The Work of Art in Digital Age. Stanford: Stanford University Press: 63-70. 